\title{
An Approach to Incorporate Rhizosphere Priming Effect into Soil Organic Matter Models
}

\section{Oleg Chertov}

Bingen University of Applied Sciences

\section{Yakov Kuzyakov}

Dept. of Soil Science of Temperate Ecosystems

\section{Irina Priputina ( $\triangle$ priputina@pbcras.ru )}

Institute of Physicochemical and Biological Problems of Soil Science RAS: Institut fiziko-himiceskih i

biologiceskih problem pocvovedenia Rossijskoj akademii nauk https://orcid.org/0000-0002-3999-4191

\section{Pavel Frolov}

Institute of Physicochemical and Biological Problems in Soil Science

Vladimir Shanin

Institute of Physicochemical and Biological Problems in Soil Science

\section{Sergey Bykhovets}

Institute of Physicochemical and Biological Problems in Soil Science

\section{Pavel Grabarnik}

Institute of Physicochemical and Biological Problems in Soil Science

\section{Research Article}

Keywords: Priming effect modelling, Root exudates, Rhizosphere interactions, Nitrogen mining, Soil food web, Available nitrogen

Posted Date: March 16th, 2021

DOl: https://doi.org/10.21203/rs.3.rs-277431/v1

License: (c) (i) This work is licensed under a Creative Commons Attribution 4.0 International License.

Read Full License 
1 An approach to incorporate rhizosphere priming effect into soil organic matter models

3 Oleg Chertov ${ }^{1}$, Yakov Kuzyakov, ${ }^{2,3,4}$, Irina Priputina, ${ }^{3, *}$, Pavel Frolov ${ }^{3}$, Vladimir Shanin ${ }^{3,5}$, Sergey

4 Bykhovets $^{3}$, Pavel Grabarnik ${ }^{3}$

$6 \quad{ }^{1}$ Bingen University of Applied Sciences, Berlin Str. 109, Bingen, 55411, Germany

$7 \quad{ }^{2}$ Dept. of Soil Science of Temperate Ecosystems, Dept. of Agricultural Soil Science, Georg-August-

8 Universität Göttingen, Büsgenweg 2, Göttingen, 37077, Germany

$9 \quad{ }^{3}$ Institute of Physicochemical and Biological Problems in Soil Science, Pushchino Scientific Center

10 for Biological Research of the Russian Academy of Sciences, Institutskaya 2, Pushchino, Moscow

11 Region, 142290, Russian Federation

$12{ }^{4}$ Agro-Technological Institute, RUDN University, Moscow, 117198, Russian Federation

$13{ }^{5}$ Center for Forest Ecology and Productivity of the Russian Academy of Sciences, Profsoyuznaya st.,

14 84/32, bld. 14, Moscow, 117997, Russian Federation

16 *corresponding author, email: priputina@pbcras.ru, ORCID 0000-0002-3999-4191

18 other email addresses and ORCIDs: oleg_chertov@hotmail.com, 0000-0002-5707-3847 19 (O.Chertov), kuzyakov@gwdg.de,0000-0002-9863-8461 (Y. Kuzyakov), frolov@pbcras.ru, 000020 0001-6564-9829 (P. Frolov), shaninvn@gmail.com, 0000-0002-8294-7796 (V. Shanin), 21 s_bykhovets@rambler.ru,0000-0002-8860-2027(S.Bykhovets),pavel.grabarnik@gmail.com,000022 0002-9732-4217 (P. Grabarnik)

\section{Acknowledgements}

25 The study was partly supported by the Russian Science Foundation, project \#18-14-00362. A 26 contribution of Yakov Kuzyakov to manuscript preparation was made with the support of the "RUDN 27 University program 5-100". 


\section{Abstract}

31 Purpose. This study is aimed to develop a model of priming effect (accelerated mineralisation of soil 32 organic matter $(\mathrm{SOM})$ ) induced by root exudate input into nitrogen $(\mathrm{N})$ limited rhizosphere soil as a 33 typical case for most terrestrial ecosystems. This ecologically important process in the functioning of the "plant-soil" system was parameterized for temperate and boreal forests.

Methods. A model of priming effect has been developed based on the concept of $\mathrm{N}$ mining to making up for the $\mathrm{N}$ scarcity in exudates by accelerating SOM mineralisation. Lacking $\mathrm{N}$ for microbial growth is mined from the SOM mineralisation considering $\mathrm{C}: \mathrm{N}$ ratio of soil. The model has a built-in food web module, which calculates soil fauna feeding on microorganisms, the release of by-products of faunal metabolism and mineral $\mathrm{N}$ used for root uptake.

Results. The model verification demonstrated the similar order of the priming effect as in the published experiments. Testing at the pedon level revealed a high sensitivity of the model to $\mathrm{N}$ content in root exudates. Testing of the model at the ecosystem level revealed that $\mathrm{CO}_{2}$ emission from the priming can reach $25-30 \%$ of $\mathrm{CO}_{2}$ emission from the whole Ah horizon of forest soil. The same intensities were simulated for the fauna-derived $\mathrm{N}$ released within the rhizosphere.

Conclusion. The new model reflects important ecological consequences of the main target function of priming effects within the "plant - soil - microorganisms - fauna" system - the microbial acceleration of $\mathrm{C}$ and $\mathrm{N}$ cycling in the rhizosphere and detritusphere to mobilise mineral $\mathrm{N}$ for plants.

Keywords: Priming effect modelling, Root exudates, Rhizosphere interactions, Nitrogen mining, Soil food web, Available nitrogen

\section{Introduction}

Crucial processes of plant-soil interactions in the rhizosphere (ones that directly influence soil

54 volume around roots) are priming effects (Cheng et al. 2014; Huo et al. 2017; Kuzyakov 2002). The rhizosphere priming effect (hereinafter referred as PE or "priming") represents an increase of microbial activity by utilization of readily available organic substrates (root exudates and other rhizodeposits) released from living roots leading to acceleration or retardation of soil organic matter (SOM) decomposition (Cheng et al. 2014; Qiao et al. 2016; Zhuravleva et al. 2018).

Root exudates (hereinafter "exudates") represent a part of plant net primary productivity

60 (NPP) and are a component of rhizodeposition (Dennis et al. 2010; Haichar et al. 2008; Lynch and

61 Whipps 1990). The exudation is dependent upon species-specific and environmental factors such as

62 plant physiology and age, roots surface area, nutrients content in roots and rhizosphere soil, and 
atmospheric $\mathrm{CO}_{2}$ concentration, among others. According to estimates (Grayston et al. 1996; Jones et al. 2009; Phillips et al. 2008), the total amount of exudates varies between 1.0 and $12.0 \%$ of the net fixed carbon (C), which is a notable part of the total C input in terrestrial ecosystems. Quantitative assessment of the organic C flows in the system of "exudates - microorganisms - rhizosphere SOM" is evaluated by ${ }^{13} \mathrm{C}$ or ${ }^{14} \mathrm{C}$ labeling and tracing, mainly under controlled conditions with annual plants or tree seedlings (Bengtson et al. 2012; Dijkstra and Cheng 2007; Jones et al. 2009). Studies focused on capturing and direct measurements of exudation from forest trees in situ are very rare (Phillips et al. 2008; Sommer et al. 2016).

The input of readily assimilated organic substances (such as free sugars, amino acids, or organic acids) in the rhizosphere triggers soil biota for an increase of SOM mineralisation and acceleration of nutrient release, primarily nitrogen $(\mathrm{N})$, available for plant roots (Bais et al. 2006; Dijkstra and Cheng 2007; Guyonnet et al. 2018). The majority of these PE mechanisms are related to the modifications of microbial activities and functioning: extracellular enzyme synthesis leading to SOM mineralisation; acceleration of microbial metabolism, consumption of microorganisms by soil fauna, change of microbial community structure and activation of various microbial groups (Blagodatskaya and Kuzyakov 2008). The existing concepts of PE mechanisms emphasise the activation of microbial metabolism to accelerate the SOM mineralisation to fill the $\mathrm{N}$ deficit in exudates for microbial growth and activity (Fontaine et al. 2003; Mason-Jones and Kuzyakov 2017; Wild et al. 2019). Nitrogen release by accelerating the SOM mineralisation ("N mining") is considered as an important integrative mechanism of priming effects (Fontaine et al. 2011).

All above assumes that coupling between root exudates, $\mathrm{C}$ and $\mathrm{N}$ availability and SOM decomposition stimulated by $\mathrm{PE}$, has to be taken into account in modelling $\mathrm{C}$ and $\mathrm{N}$ cycling in soils and ecosystems, especially under climate or land-use changes. Incorporation of PE mechanisms into soil and ecosystem models is needed to precisely simulate trajectories of plant production and soil C storage under future conditions (Dijkstra et al. 2020; Perveen et al. 2014).

The first attempt for priming modelling was done more than 40 years ago (Parnas 1976), where a general accent was made on the role of microbial activity. Until now, a dominating approach in the PE modelling is a reproduction of the priming phenomenon similar to laboratory experiments with the main focus on $\mathrm{C}$ fluxes, soil microbial growth and activity (Blagodatsky et al. 2010; Cheng et al. 2014; Wutzler and Reichstein 2013).

The alternative approach in PE modelling assumes the use of the ecological stoichiometry concept coupling with a theory of resource availability considering nutrient demands of microorganisms and plants (Cleveland and Liptzin 2007; Frost et al. 2005; Schimel and Weintraub 2003). We suppose this point of view is more suitable to model PE depending on the exudate release 
into soil at the ecosystem scale (plant - soil system). We simulated the $\mathrm{C}$ and $\mathrm{N}$ cycles in the rhizosphere, including $\mathrm{C}$ input and sequestration as well as mineral $\mathrm{N}$ release and cycling, as important priming functions in nutrient-limited ecosystems.

This study is aimed to develop a model of priming induced by root exudate input into Nlimited soil, which is a typical case for most natural terrestrial ecosystems in temperate and boreal zones. The developed model can be a module linked with the SOM and terrestrial ecosystem models, where this pattern of plant - soil interactions is still not considered (Bengtson et al. 2012; Komarov et al. 2017; Sándor et al. 2020). In addition to calculating the $\mathrm{CO}_{2}$ flux due to the mineralisation of various sources, the combination of SOM and priming models allowed the estimation of the contribution of microbial growth induced by exudate input to produce SOM and available $\mathrm{N}$ in food webs of soil biota.

\section{Materials and methods}

\section{Model description}

The main postulates when compiling the priming model were as follows: (a) the released root exudates are fully consumed by MO within 1-5 days (Ekblad and Högberg 2001; Liu et al. 2019); (b) microbial growth due to exudates is limited by the lack of $\mathrm{N}$, and part of the exudates $\mathrm{C}$ remains without $\mathrm{N}$ for microbial growth (Chen et al. 2019); (c) this $\mathrm{N}$ limitation is compensated by $\mathrm{N}$ mining from the SOM (Chen et al. 2014; Cui et al. 2020; Fontaine et al. 2011); and (d) the built-in food web procedure in the model calculates consumption of microorganisms by soil fauna, whereas the released products of faunal metabolism and especially mineral N, can be used by plants (Clarholm 1985, 1989, Holtkamp et al. 2011).

The model has a daily time step, and it is valid for PE induced by exudate input into the soil with $\mathrm{N}$ deficiency, which takes place in a vast majority of natural soils of temperate climate. In addition to simulate the dynamics of SOM and microbial biomass, the model includes a food web module by the approach of Chertov et al. (2017). The food web module assesses available $\mathrm{N}$ and SOM production at the food web functioning. The structure of the model is represented in Fig. 1.

The $\mathrm{N}$ pool in the exudates is not enough to use all $\mathrm{C}$ for microbial growth. For instance, according to the data by Kuzyakov et al. (2007), exudates contain 15\% amino acids, which correspond to $1.25 \% \mathrm{~N}$ and $\mathrm{C}: \mathrm{N}=40$ in the whole material. We assume the microorganisms are consuming all the exudate $\mathrm{N}$, and, therefore, microbial biomass growth due to this $\mathrm{N}$ can be defined as:

$$
G_{r e}=N_{r e} \times C N_{m o} \times A_{m o},
$$

where $G_{r e}$ is the growth of microbial biomass C, $C N_{m o}$ is the C:N ratio of microbial biomass, $N_{r e}$ is the $\mathrm{N}$ pool in exudates, and $A_{m o}$ is the assimilation efficiency of the exudate $\mathrm{N}$ by microorganisms. In 
the model, $A_{m o}$ is equal to 1.00 (Holtkamp et al. 2011).

The C:N ratio of microbial biomass was determined by the function compiled according to data of Chertov et al. (2017):

$$
C N_{\text {mo }}=C N_{\text {bact }}+\frac{\left(C N_{\text {fung }}-C N_{\text {bact }}\right)}{\left(1+\exp \left(-0.49 *\left(C N_{\text {SOM }}-13.23\right)\right)\right)},
$$

where $C N_{S O M}$ is a rhizosphere soil C:N ratio, $C N_{\text {bact }}$ is a $\mathrm{C}: \mathrm{N}$ ratio of bacteria community (taken equal to 5) and $C N_{\text {fung }}$ is a $\mathrm{C}: \mathrm{N}$ ratio of fungi community (taken equal to 11 ).

A substantial part of the exudate $\mathrm{C}$ is used for respiration during microbial growth:

$$
R_{r e}=G_{r e} \times \frac{\left(1-P_{e f f}\right)}{P_{e f f}},
$$

where $R_{r e}$ is the respiration for microbial growth and $P_{e f f}$ is the production efficiency of microorganisms (as used in soil food web studies; $P_{\text {eff }}$ corresponds to the "carbon use efficiency", CUE, in microbiology). These eco-physiological parameters of $\mathrm{C}$ assimilation are tightly linked $\left(R_{r e}+P_{\text {eff }}=1.0\right)$. In the model, $P_{\text {eff }}$ is equal to 0.30 (Holtkamp et al. 2011) that is lower than CUE in most short-term experiments (Dijkstra et al. 2015; Geyer et al. 2019) because longer time periods are considered in the model.

The rest of exudates that cannot be used for microbial growth due to $\mathrm{N}$ deficiency is determined by the following function:

$$
E_{r e}=C_{r e}-G_{r e}-R_{r e}
$$

where $E_{r e}$ is the remains of exudates after consumption for microbial growth and $C_{r e}$ is the exudates pool.

Part of the exudates remains in the soil after the consumption of all $\mathrm{N}$ for microbial growth. The new microbial biomass, after the use of exudate $\mathrm{N}$, accelerates the mineralisation of the rhizosphere SOM and thus the $\mathrm{N}$ release, which is actually "N mining". We assume that due to $\mathrm{N}$ mining, the rest of exudates will be used for additional microbial growth, $G_{\text {exc }}$, and for growth respiration, $R_{\text {exc }}$ :

$$
\begin{gathered}
G_{e x c}=E_{r e} \times P_{e f f}, \\
R_{e x c}=E_{r e} \times\left(1-P_{e f f}\right),
\end{gathered}
$$

where $P_{\text {eff }}$ is defined above.

It follows that $\mathrm{N}$ mining itself, $N M$, can be represented as follows:

$$
N M=\frac{G_{e x c}}{C N_{m o}} \times N M_{e f f} .
$$

Since the experimental data on $\mathrm{N}$ mining rate is insufficient, a calibration factor of $\mathrm{N}$ mining 
efficiency, $N M_{\text {eff }}(0 \ldots 1.0)$ was introduced to reduce $\mathrm{N}$ mining in a case of impossibility to cover all $\mathrm{N}$ demand of the remaining exudates for surplus of microbial growth.

The acceleration of rhizosphere SOM mineralisation for $\mathrm{N}$ mining is calculated as:

$$
R_{n m}=N M \times C N_{S O M},
$$

where $R_{n m}$ is an additional respiration $\mathrm{C}$ used for $\mathrm{PE}$, and $C N_{S O M}$ is defined above.

Calculated microbial biomass enters the module of the food web (FW), described in detail by Chertov et al. (2017). In this procedure, microorganisms are consumed by "microbial grazers" (protozoans, nematodes and microarthropods) with ammonium release used for root uptake (Clarholm 1985, 1989; Holtkamp et al. 2011). This trophic level serves as food for the upper food web levels, where microbial grazers are consumed by soil mesofauna with the formation of excrements and necromass, which are returning to SOM.

Finally, the priming effect is calculated as carbon of all respiration flows:

$$
P E_{\text {tot }}=R_{r e}+R_{\text {exc }}+R_{n m}+R_{f w},
$$

where $R_{f w}$ is the faunal respiration in soil food webs; the others are described above. It should be emphasised that the term of this equation, $R_{n m}$, represents a "net" priming, i.e. an excessive soil respiration when the microorganisms are activated to mine nitrogen in the SOM of the rhizosphere.

The mineralisation rates of exudates and SOM were set at 0.50 (Gunina and Kuzyakov 2015; Jones et al. 2005) and $0.00018 \mathrm{day}^{-1}$ (Komarov et al. 2017), respectively. Correction factors for the influence of temperature and moisture on the mineralisation rates are taken from Komarov et al. (2017). Other model parameters are summarized in Table 1. The software implementation of the model was made in Pascal programming language in the Lazarus 2.0.6 IDE.

\section{Verification}

Model verification was carried out using experimental data of two studies (Blagodatsky et al. 2010; Qiao et al. 2016), where whole PE was determined by the ${ }^{13} \mathrm{C}$ or ${ }^{14} \mathrm{C}$ isotopic labelling in the experiments in controlled conditions. One study was performed with agricultural soil in a temperate climate (the Ah horizon of a loamy Haplic Luvisol, $\mathrm{C}_{\mathrm{org}}=2.4 \%, \mathrm{C}: \mathrm{N}=12$ ); the other one was performed with forest soil in subtropical climate (the $\mathrm{O}_{\mathrm{a}}$ and $\mathrm{Ah}$ horizons of Alfisols, $\mathrm{C}_{\mathrm{org}}=42.5$ and 10.5\%, C:N = 19 and 16, respectively). The initial data, temperature and soil moisture for the model run were identical to the data used in the experiments.

\section{Scenarios of model runs Testing at the pedon level}

Model testing was performed at temperature $20^{\circ} \mathrm{C}$ and soil volumetric moisture of $60 \%$ with 
a set of runs by the matrix [exudate input] $\times$ [exudate $\mathrm{C}: \mathrm{N}$ ] with exudate input from 0.5 to $2.0 \mathrm{~g}[\mathrm{C}] \mathrm{m}^{-2}$ day $^{-1}$ and for their $\mathrm{C}: \mathrm{N}$ range from 10 to 80 reflecting its possible minimal and maximal values. The stocks of $\mathrm{C}$ and $\mathrm{N}$ in rhizosphere soils considered only in a small volume around the roots were 3.22 and $0.23 \mathrm{~kg} \mathrm{~m}^{-2}$, respectively. Model parameters are listed in Table 1.

\section{Testing at the ecosystem level}

The model was tested at the ecosystem level with the data from the mixed forest in the southern boreal zone of Eastern Europe (Chertov et al. 2011). The average NPP of tree stands was estimated as $0.375 \mathrm{~kg}[\mathrm{C}] \mathrm{m}^{-2}$ year $^{-1}$. The soil was Moder loamy Retisol of well-drained moraine plain. The growing season duration was 225 days.

The simulation was run for conditions of midsummer for 30 days. The soil temperature was set at $16^{\circ} \mathrm{C}$ with optimal soil moisture. Two rates of root exudation were simulated to reflect a spatial mosaic of plant communities in mixed forest. The first one was calculated on the basis of the data for 25-years pine plantation (Phillips et al. 2008), where root exudate flow was estimated as 3\% of the NPP. It corresponds to $3 \mathrm{~g}[\mathrm{C}] \mathrm{m}^{-2} \mathrm{month}^{-1}$ based on the NPP data from Chertov et al. (2011). This value was considered as a minimal estimate. The second rate of exudate flow reflects a higher magnitude of $15 \mathrm{~g}[\mathrm{C}] \mathrm{m}^{-2}$ month $^{-1}$ for 0-15 $\mathrm{cm}$ layer that was shown in the experiment with 6-month coniferous seedlings (Bengtson et al. 2012). The value of $15 \mathrm{~g}[\mathrm{C}] \mathrm{m}^{-2} \mathrm{month}^{-1}$ was assumed to be a maximal estimate.

The exudate and the SOM mineralisation rates in bulk and rhizosphere soil were the same as in Section "Model description". The rate of microbial biomass consumption by soil fauna of food webs was estimated at $0.15 \mathrm{day}^{-1}$ for bacteria and $0.06 \mathrm{day}^{-1}$ for fungi (Chertov et al. 2017; Coleman 1994; de Vries et al. 2013). Initial data for testing on the ecosystem level are presented in Table 1. Two options of exudates input were used: (a) one pulse at the start of the model run was used for the verification and testing at the pedon level, and (b) everyday input as takes place in natural conditions was used for the testing at the ecosystem level.

\section{Results}

\section{Model verification}

The model demonstrated the same order of PE intensities as in the experiments. However, the full consistency of the simulation results with experimental data was not observed. In the case of full $\mathrm{N}$ mining efficiency $(k=1)$, the model overestimates the experimental results by 1.2 to 1.6 times but without significant difference between experimental and modelled data (Fig. 2).

The results of the model runs showed some peculiarities of the model behaviour. The PE 
clearly depends on the $\mathrm{N}$ mining to make up for its deficit for microbial growth (varying by the $\mathrm{N}$ mining efficiency by factor $k=0 \ldots 1$ ). The share of microbial biomass $\mathrm{N}$ due to $\mathrm{N}$ mining from rhizosphere SOM was $51 \%$ at the efficiency factor $k=1.0$ and $35 \%$ at $k=0.5$, which clearly shows the importance of $\mathrm{N}$ mining for microbial life. The SOM mineralisation rate in the rhizosphere after the exudate input was accelerated for 3-15 times compared to bulk soil due to $\mathrm{N}$ mining.

\section{Model testing on the pedon level}

A set of model runs on the level of a single profile with the variation of exudate and microbial community parameters showed interesting results on the influence of several factors on PE. These results revealed similarity between two exudate input patterns at a 20-day simulation: one impulse at the start of a model run or by continuous input (i.e. on a daily basis) as it takes place in natural conditions.

In this simulation, the modelled PE were clearly dependent both on the amounts of exudates entering the soil and especially on their $\mathrm{C}: \mathrm{N}$ ratios reflecting the exudate richness with N. Fig. 3 shows that $\mathrm{CO}_{2}$ emission by PE can exceed exudate $\mathrm{C}$ input by $1-2 \%\left(0.02 \mathrm{~g}[\mathrm{C}] \mathrm{m}^{-2}\right)$ at $\mathrm{C}: \mathrm{N}=10$, but reaches $60 \%\left(1.25 \mathrm{~g}[\mathrm{C}] \mathrm{m}^{-2}\right)$ at exudates $\mathrm{C}: \mathrm{N}=80$, i.e., the lower the $\mathrm{N}$ content in the incoming exudate is (high $\mathrm{C}: \mathrm{N}$ ratio), the higher is the PE.

Another picture emerges when comparing the per cent of extra mineralised $\mathrm{C}$ due to $\mathrm{N}$ mining to the whole exudates $\mathrm{C}$ input $\left(R_{n m}\right)$ with various exudate $\mathrm{C}: \mathrm{N}$ ratios (Fig. 4$)$. In this case, a close dependence of $R_{n m}$ only on the C:N ratio is noted. This dependence is the same at all levels of exudates inflow. It can be expressed by the following logistic function:

$$
\frac{R_{n m}}{C_{r e}} \times 100=\frac{60.0}{1+57.0 \times e^{0.13 \times C N_{r e}}},
$$

where $C N_{r e}$ is the C:N ratio of exudates $(10<\mathrm{C}: \mathrm{N}<80)$, and $\frac{R_{n m}}{C_{r e}} \times 100$ is the $R_{n m}, \%$ of exudates input $\left(\mathrm{R}^{2}=0.98\right)$.

Model runs were carried out with a range of microbial $\mathrm{C}: \mathrm{N}$ ratio within the actual values for bacterial and fungal communities (Cleveland and Liptzin 2007; Sterner and Elser 2002). PE strongly decreases if the microbial community has a high $\mathrm{C}: \mathrm{N}$ ratio, which means domination by organisms with a low $\mathrm{N}$ demand (e.g. mainly fungi). In contrast, a microbial community with low $\mathrm{C}: \mathrm{N}$ has a high $\mathrm{N}$ demand, resulting in a larger PE (Fig. 5).

Finally yet importantly, the amount of $\mathrm{N}$ available to plants (mainly ammonia) produced by food webs is comparable with the $\mathrm{N}$ pool in the exudates. Thus, the sum of excessive $\mathrm{N}$ at the "microbial grazers" level of the food web as available for root uptake $\mathrm{N}$ plus excrements and necromass $\mathrm{N}$ can exceed the pool of $\mathrm{N}$ coming with exudates by $40 \%$. This available $\mathrm{N}$ depends 
linearly on the amount of incoming exudates and especially on their $\mathrm{N}$ pool.

Thus, $\mathrm{N}$ mineralised from SOM ( $\mathrm{N}$ mining) is used by microorganisms for growth, followed by the feeding of fauna on microorganisms in food webs with the release of excessive $\mathrm{N}$ at the level of "microbial grazers" and production of N-rich excrements and necromass (Clarholm 2005; Holtkamp et al. 2011).

\section{Model testing at the ecosystem level}

Model testing at the ecosystem level accounts for both the processes in the rhizosphere soil and the entire organo-mineral horizon (Ah) of the forest soil. The simulated data on processes occurring in the rhizosphere with only $1.3 \% \mathrm{C}$ of the whole Ah horizon are comparable in magnitude with data across the entire Ah horizon.

Depending on the rate of exudates flow, the $\mathrm{CO}_{2}$ emitted by priming was 15.4 (at maximum) and $3.2 \mathrm{~g}[\mathrm{C}] \mathrm{m}^{-2}$ month ${ }^{-1}$ (at minimum) that is comparable with the $\mathrm{CO}_{2}$ emission from the entire Ah horizon $\left(36.0 \mathrm{~g}[\mathrm{C}] \mathrm{m}^{-2}\right.$ month $\left.^{-1}\right)$. At the same time, the $\mathrm{CO}_{2}$ emission from a small volume of rhizosphere soil in absence of PE reaches only $0.49 \mathrm{~g}[\mathrm{C}] \mathrm{m}^{-2} \mathrm{month}^{-1}$. Mineralised carbon from SOM at $\mathrm{N}$ mining $\left(R_{n m}\right)$ amounts for $3-8 \%$ of the released exudate carbon.

The rate of organic matter mineralisation reflects active growth and functioning of microorganisms in the rhizosphere. Microbial biomass growth rates in the rhizosphere (Fig. 6) are significantly faster than in the root-free soil because of excess of available $\mathrm{C}$ in the rhizosphere and the nearly steady state conditions for microorganisms in the non-rhizosphere soil (Blagodatskaya et al. 2010, 2014). Microbial biomass in the forest soil of the boreal zone is about $3.5 \%$ from the SOM pool (Chertov et al. 2017) and is $3.15 \mathrm{~g}[\mathrm{C}] \mathrm{m}^{-2}$ in the rhizosphere soil. With such a $\mathrm{C}$ pool of microbial biomass, the calculated microbial growth can reach up to $5 \%$ per day.

At the maximum exudation $\left(15 \mathrm{~g}[\mathrm{C}] \mathrm{m}^{-2}\right.$ month $\left.^{-1}\right)$, the amount of $\mathrm{N}$ mineralised from SOM

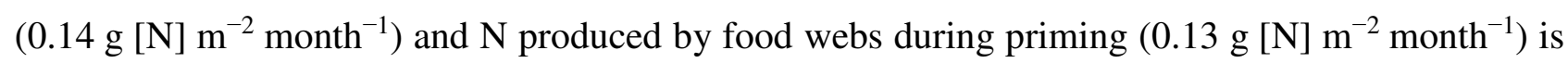
comparable with $\mathrm{N}$ released from root exudates $\left(0.38 \mathrm{~g}[\mathrm{~N}] \mathrm{m}^{-2} \mathrm{month}^{-1}\right)$. The same dependence retains for conservative estimate of exudates pool $\left(3 \mathrm{~g}[\mathrm{C}] \mathrm{m}^{-2} \mathrm{month}^{-1}\right)$. Depending on the rate of exudates flow, the sum of $\mathrm{N}$ fluxes involved in the rhizosphere priming varies between $6-21 \%$ of the total pool of mineralised $\mathrm{N}$ during one month in the whole Ah horizon $\left(2.05 \mathrm{~g}[\mathrm{~N}] \mathrm{m}^{-2} \mathrm{month}^{-1}\right)$. These amounts exceed 5-20 times the $\mathrm{N}$ mineralisation in the rhizosphere $\left(0.027 \mathrm{~g}[\mathrm{~N}] \mathrm{m}^{-2} \mathrm{month}^{-1}\right)$ without exudates input (Fig. 7).

This testing accounted for the entire Ah horizon and the exudate flow from tree roots into the rhizosphere allowed to estimate $\mathrm{C}$ and $\mathrm{N}$ fluxes in the forest soil at priming (Fig. 8). It shows a significant difference in the $\mathrm{C}$ and $\mathrm{N}$ flows structure at priming functioning. 


\section{Discussion}

The approach proposed here is to model the most common type of rhizosphere $\mathrm{PE}-\mathrm{N}$ mining from SOM - when the root exudates enter the soil. The model allows for a quantitative estimation of general PE data of soil $\mathrm{C}$ dynamics ( $\mathrm{CO}_{2}$ emission by mineralisation of exudates and $\left.\mathrm{SOM}\right)$ that is a main aspect in the PE studies (Blagodatsky et al. 2010; Kuzyakov 2002; Mason-Jones and Kuzyakov 2017). The principal point in the model structure was to use the concept of $\mathrm{N}$ mining to meet the microbial demand for growth as a key factor in priming SOM mineralisation. A specific feature of the simulation approach is the inclusion of a food web module into the model structure (Chertov et al. 2017; Holtkamp et al. 2011; de Vries et al. 2013), in which soil fauna consumes microbial biomass and releases mineral $\mathrm{N}$, as well as metabolic by-products, returned to SOM. In fact, the mineral N production by food webs in priming is the important ecological feedback in the PE functioning (Clarholm 2005), which answers the question of why plants release some $\mathrm{N}$ in nitrogen-limited environments (Wichern et al. 2007): the additional mineral $\mathrm{N}$ mineralisation within PE is comparable with $\mathrm{N}$ excretion with root exudates. This $\mathrm{N}$ surplus leads to the improvement of plant nutrition and an increase in ecosystem stability.

Previously, nearly all PE experiments were done with a start pulse addition of glucose or exudates (Kuzyakov 2002; Qiao et al. 2016). There are only a few priming effect studies with frequent or continuous addition of organic compounds (Qiao et al. 2014) or plant growth with continuous labelling (He et al. 2020; Pei et al. 2020; Zhou et al. 2020). The model calculation of two patterns of exudates input revealed similarity between excretion as one impulse at the start of a model run or by everyday input at the 30-day time interval, though this difference takes place at long-term experiments (Wu et al. 2020).

Model testing showed a fast response of the simulated PE to the $\mathrm{N}$ content in exudates $(\mathrm{C}: \mathrm{N}$ ratio). The lower the $\mathrm{N}$ content of the exudates (high $\mathrm{C}: \mathrm{N}$ ), the higher $\mathrm{CO}_{2}$ emission by priming is, which follows experimental data (Qiao et al. 2016). Accordingly, the less $\mathrm{N}$ in exudates, the higher

312 the $\mathrm{N}$ mining intensity is. The influence of microbial biomass $\mathrm{C}: \mathrm{N}$ on priming is opposite: the higher 313 the $\mathrm{N}$ demand is (low microbial biomass $\mathrm{C}: \mathrm{N}$ ), the more intensive $\mathrm{N}$ mining and $\mathrm{PE}$ are to cover $\mathrm{N}$ 314 deficiency.

Ecosystem-scale model testing reflects the situation with a full exudate uptake and utilisation

316 by microorganisms due to $\mathrm{N}$ of exudates and $\mathrm{N}$ mining, and full microbial biomass consumption by 317 the fauna. The simulation results quantitatively assess the contribution of $\mathrm{PE}$ to the total $\mathrm{CO}_{2}$ emission 318 as an important process that can reach up to one third of the $\mathrm{CO}_{2}$ emission from the soil. The impact 319 of $\mathrm{PE}$ on $\mathrm{CO}_{2}$ emission from soil was stronger than on $\mathrm{N}$ mineralisation. However, in most soils in 
320

321

322

temperate and boreal forests, $\mathrm{N}$ is the main limiting factor determining the trophic status of forest ecosystems. From this point of view, the impact of priming on the increase of mineral $\mathrm{N}$ production is an ecologically more important process.

So far, $\mathrm{N}$ mining has been considered as a significant process in the PE phenomenon, regulating $\mathrm{CO}_{2}$ emissions (Blagodatsky et al. 2010; Kuzyakov 2002; Zhuravleva et al. 2018). In contrast to the previous studies, $\mathrm{N}$ in this model is also a rate variable driving the transformation processes through the $\mathrm{C}: \mathrm{N}$ ratio. This is a new aspect of PE modelling, which has provided an opportunity to understand the role of PE in terrestrial ecosystems. Based on the results of the model runs with a $20 \%$ increase in mineral $\mathrm{N}$ output to the soil as a whole, $\mathrm{PE}$ is a mechanism for additional mineralisation of $\mathrm{N}$ stored in SOM. This $\mathrm{N}$ is available for the root uptake and nutrition by vegetation, thus increasing its productivity and stability. This can be interpreted as a "target function" of the priming effect.

There are some sources of uncertainty in this modelling approach: (a) $\mathrm{N}$ mining is presented as a "black box" without detailed biochemical mechanisms for accelerating SOM mineralisation to obtain additional $\mathrm{N}$ for microbial growth. (b) The used eco-physiological parameters of microorganisms (assimilation and production efficiency of consumed organic matter) may differ from the real one. (c) The actual input of root exudates needs to be specified. According to Pausch et al. (2013), annual production of exudates is $166 \mathrm{~kg}^{\mathrm{C}}[\mathrm{C}] \mathrm{ha}^{-1} \mathrm{year}^{-1}$, which corresponds to $0.2 \mathrm{~g}[\mathrm{C}] \mathrm{m}^{-2} \mathrm{day}^{-1}$ for a 3 -month vegetation period. In our simulation, calculating the flow of exudates as $3 \%$ of the net primary productivity in forest ecosystem with the growing season duration equal to 225 days (Chertov et al., 2011) resulted in a figure of $0.1 \mathrm{~g}[\mathrm{C}] \mathrm{m}^{-2} \mathrm{day}^{-1}$. (d) Soil macrofauna respiration of the upper levels of the food web that was not related to SOM mineralisation (Holtkamp et al. 2011) was not considered. (e) Testing of the model at the ecosystem level was performed without accounting for fluctuations in soil temperature and moisture common in natural environment. Therefore, the results of the model runs can be considered as the potential maximum output of PE.

In the context of further development of PE modelling, some uncertainties should be clarified when including PE model into the terrestrial ecosystem models. First, the amount of exudates delivered directly to mycorrhizal symbionts bypassing the soil is necessary to be considered (Deckmyn et al. 2014; Zhou et al. 2020). On the other hand, ectomycorrhiza is a source of liquid excreta and enzymes (e.g. chitinase), and easily decomposable N-rich organics (e.g. chitin) remains after its mortality (Godbold et al. 2006), and consequently, mycorrhiza support the PE functioning. It should be noted that an important requirement for improving this PE model, which combines the microbiological and faunal components of soil biota, is to obtain experimental data on the $\mathrm{N}$ 
mining, the amount and composition of root exudates as well as mineral N production (Murphy et al. 2015; Zhu et al. 2014). This requires new experimental data to be obtained.

\section{Conclusions}

The proposed priming effect model is based on the concept of nitrogen $(\mathrm{N})$ mining from SOM combined with a soil food web module. The model testing showed high relevance of the $\mathrm{N}$ content both in root exudates and in microbial biomass. A decrease in the $\mathrm{N}$ pool in exudates increased priming, but a decrease in the $\mathrm{N}$ content in microbial biomass has the opposite action $-\mathrm{N}$ mining decrease. The $\mathrm{C}$ and $\mathrm{N}$ amounts released within the priming are much higher than their amounts in the root exudates and so, are very relevant $\mathrm{N}$ source for plant uptake. Testing the model with linkage to the entire Ah horizon revealed the high importance of priming at an ecosystem level: $\mathrm{CO}_{2}$ emission from the priming effect can reach up to $25-30 \%$ of $\mathrm{CO}_{2}$ released from the Ah horizon. The production of mineral $\mathrm{N}$ at priming is also comparable with the $\mathrm{N}$ input with exudates. This $\mathrm{N}$ excess justifies the root's outflow of $\mathrm{N}$ to obtain its additional pool from the rhizosphere for increased plant growth and stability. In general, model structure and modelling results allow priming simulation under real environmental conditions. The model is supposed to be valid for a wide range of edaphic conditions and soils in a boreal and temperate climate.

\section{Declarations}

Funding. The study was partly supported by the Russian Science Foundation, project \#18-14-00362. A contribution of Yakov Kuzyakov to manuscript preparation was made with the support of the "RUDN University program 5-100".

Conflicts of interest. The authors declare no conflict of interests.

Ethics approval. Not applicable.

Consent to participate. Not applicable.

Consent for publication. Not applicable.

Availability of data and material. The data are available from authors by reasonable request.

Code availability. The source code is available from authors by reasonable request.

Authors' contributions. All authors contributed to the concept, development and compilation of the model. Algorithm compilation and model parameters collection were performed by Oleg Chertov and Yakov Kuzyakov. Programming was produced by Pavel Frolov, Vladimir Shanin and Sergey Bykhovets. The first draft of the manuscript was written by Oleg Chertov and Irina Priputina. Internal text editing was performed by Yakov Kuzyakov and Pavel Grabarnik. All authors commented on previous versions of the text, read and approved the final manuscript. 


\section{References}

Bais HP, Weir LP, Perry LG, Gilroy S, Vivanco JM (2006) The role of root exudates in rhizosphere interactions with plants and other organisms. Annu Rev Plant Biol 57:233-266.

$$
\text { https://doi.org/10.1146/annurev.arplant.57.032905.105159 }
$$

Bengtson P, Barker J, Grayston SJ (2012) Evidence of a strong coupling between root exudation, C and $\mathrm{N}$ availability, and stimulated SOM decomposition caused by rhizosphere priming effects. Ecol Evol 2(8):1843-1852. https://doi.org/10.1002/ece3.311

Blagodatskaya E, Blagodatsky S, Anderson TH, Kuzyakov Y (2014) Microbial growth and carbon use efficiency in the rhizosphere and root-free soil. PLOS ONE 9(4):e93282. https://doi.org/10.1371/journal.pone.0093282

Blagodatskaya E, Blagodatsky S, Dorodnikov M, Kuzyakov Y (2010) Elevated atmospheric CO2 increases microbial growth rates in soil: results of three $\mathrm{CO}_{2}$ enrichment experiments. Glob Change Biol 16:836-848. https://doi.org/10.1111/j.1365-2486.2009.02006.x

Blagodatskaya E, Kuzyakov Y (2008) Mechanisms of real and apparent priming effects and their dependence on soil microbial biomass and community structure: critical review. Biol Fert Soils 45(2):115-131. https://doi.org/10.1007/s00374-008-0334-y

Blagodatsky S, Blagodatskaya E, Yuyukina T, Kuzyakov Y (2010) Model of apparent and real priming effects: Linking microbial activity with soil organic matter decomposition. Soil Biol Biochem 42:1275-1283. https://doi.org/10.1016/j.soilbio.2010.04.005

Chen J, Seven J, Zilla T, Dippold MA, Blagodatskaya E, Kuzyakov Y (2019) Microbial C:N:P stoichiometry and turnover depend on nutrient availability in soil: a ${ }^{14} \mathrm{C},{ }^{15} \mathrm{~N}$ and ${ }^{33} \mathrm{P}$ triple labelling study. Soil Biol Biochem 131:206-216. https://doi.org/10.1016/j.soilbio.2019.01.017

Chen R, Senbayram M, Blagodatsky S, Myachina O, Dittert K, Lin X, Blagodatskaya E, Kuzyakov Y (2014) Soil C and N availability determine the priming effect: microbial $N$ mining and stoichiometry theories. Global Change Biol 20(7):2356-2367. https://doi.org/10.1111/gcb.12475

Cheng W, Parton WJ, Gonzalez-Meler MA, Phillips R, Asao S, McNickle GG, Brzostek E, Jastrow JD (2014) Synthesis and modelling perspectives of rhizosphere priming. New Phytol 201:3156. https://doi.org/10.1111/nph.12440

Chertov OG, Gryazkin AV, Smirnov AP, Kovalev NV (2011) Change of carbon balance and biological productivity of the forest stands at different managing regimes. Proc St Petersburg 
For Tech Univ 197:263-272. In Russian.

Chertov O, Komarov A, Shaw C, Bykhovets S, Frolov P, Shanin V, Grabarnik P, Priputina I, Zubkova soil biota activity. II. Parameterisation of the soil food web biota activity. Ecol Model 345:125-139. https://doi.org/10.1016/j.ecolmodel.2016.10.024

Clarholm M (1985) Interactions of bacteria, protozoa and plants leading to mineralization of soil nitrogen. Soil Biol Biochem 17:181-187. https://doi.org/10.1016/0038-0717(85)90113-0

Clarholm M (1989) Effects of plant-bacterial-amoebal interactions on plant uptake of nitrogen under field conditions. Biol Fert Soils 8:373-378. https://doi.org/10.1007/BF00263171

Clarholm M (2005) Soil protozoa: an under-researched microbial group gaining momentum. Soil Biol Biochem 37:811-817. https://doi.org/10.1016/j.soilbio.2004.11.002

Cleveland CC, Liptzin D (2007) C:N:P stoichiometry in soil: is there a "Redfield ratio" for the microbial biomass? Biogeochemistry 85:235-252. https://doi.org/10.1007/s10533-007-91320

Coleman DS (1994) The microbial loop concept as used in terrestrial soil studies. Microb Ecol 28:245-250. https://doi.org/10.1007/BF00166814

Cui J, Zhu Z, Xu X, Liu S, Jones DL, Kuzyakov Y, Wu J, Ge T (2020) Carbon and nitrogen recycling from microbial necromass to cope with $\mathrm{C}: \mathrm{N}$ stoichiometric imbalance by priming. Soil Biol Biochem 142:107720. https://doi.org/10.1016/j.soilbio.2020.107720

de Vries FT, Thébault E, Liiri M, Birkhofer K, Tsiafouli MA, Bjørnlund L, Jørgensen HB, Brady, MV, Christensen S, de Ruiter PC, d'Hertefeldt T, Frouz J, Hedlund K, Hemerik L, Hol WHG, Hotes S, Mortimer SR, Setälä H, Sgardelis SP, Uteseny K, van der Putten WH, Wolters V, Bardgett RD (2013) Soil food web properties explain ecosystem services across European land use systems. PNAS 110:14296-14301. https://doi.org/10.1073/pnas.1305198110

Deckmyn G, Meyer A, Smits MM, Ekblad A, Grebenc T, Komarov A, Kraigher H (2014) Simulating ectomycorrhizal fungi and their role in carbon and nitrogen cycling in forest ecosystems. Can J For Res 44:535-553. https://doi.org/10.1139/cjfr-2013-0496

Dennis PG, Miller AJ, Hirsch PR (2010) Are root exudates more important than other sources of rhizodeposits in structuring rhizosphere bacterial communities? FEMS Microbiol Ecol 72:313-327. https://doi.org/10.1111/j.1574-6941.2010.00860.x

Dijkstra FA, Cheng W (2007) Interactions between soil and tree roots accelerate long-term soil carbon decomposition. Ecol Lett 10(11):1046-1053. https://doi.org/10.1111/j.14610248.2007.01095.x

Dijkstra P, Salpas E, Fairbanks D, Miller EB, Hagerty SB, van Groenigen KJ, Hungate BA, Marks 

JC, Koch GW, Schwartz E (2015) High carbon use efficiency in soil microbial communities is related to balanced growth, not storage compound synthesis. Soil Biol Biochem 89:35-43. https://doi.org/10.1016/j.soilbio.2015.06.021

Dijkstra FA, Zhu B, Cheng W (2020) Root effects on soil organic carbon: a double-edged sword. New Phytol. https://doi.org/10.1111/nph.17082

Ekblad A, Högberg P (2001) Natural abundance of ${ }^{13} \mathrm{C}$ in $\mathrm{CO}_{2}$ respired from forest soils reveals speed of link between tree photosynthesis and root respiration. Oecologia 127:305-308. https://doi.org/10.1007/s004420100667

Fontaine S, Mariotti A, Abbadie L (2003) The priming effect of organic matter: a question of microbial competition? Soil Biol Biochem 35:837-843. https://doi.org/10.1016/S00380717(03)00123-8

Fontaine S, Henault C, Aamor A, Bdioui N, Bloor JMG, Maire V, Mary B, Revaillot S, Maron PA (2011) Fungi mediate long term sequestration of carbon and nitrogen in soil through their priming effect. Soil Biol Biochem 43:86-96. https://doi.org/10.1016/j.soilbio.2010.09.017

Frost PC, Evans-White MA, Finkel ZV, Jensen TC, Matzek V (2005) Are you what you eat? Physiological constraints on organismal stoichiometry in an elementally imbalanced world. Oikos 109:18-28. https://doi.org/10.1111/j.0030-1299.2005.14049.x

Geyer KM, Dijkstra P, Sinsabaugh R, Frey SD (2019) Clarifying the interpretation of carbon use efficiency in soil through methods comparison. Soil Biol Biochem 128:79-88. https://doi.org/10.1016/j.soilbio.2018.09.036

Godbold DL, Hoosbeek MR, Lukac M, Cotrufo MF, Janssens IA, Ceulemans R, Polle A, Velthorst EJ, Mugnozza G, De Angelis P, Miglietta F, Peressott A (2006) Mycorrhizal hyphal turnover as a dominant process for C input into soil organic matter. Plant Soil 281:15-24. https://doi.org/10.1007/s11104-005-3701-6

Grayston SJ, Vaughan D, Jones D (1996) Rhizosphere carbon flow in trees, in comparison with annual plants: the importance of root exudation and its impact on microbial activity and nutrient availability. Appl Soil Ecol 5: 29-56. https://doi.org/10.1016/S0929-1393(96)001266

Gunina A, Kuzyakov Y (2015) Sugars in soil and sweets for microorganisms: Review of origin, content, composition and fate. Soil Biol Biochem 90:87-100. https://doi.org/10.1016/j.soilbio.2015.07.021

Guyonnet JP, Gullemet M, Dubost A, Simon L, Ortet P, Barakat M, Heulin T, Achouk W, el Zahar Haichar F (2018) Plant nutrient resource use strategies shape active rhizosphere micribiota through root exudation. Front Plant Sci 9:1662. https://doi.org/10.3389/fpls.2018.01662 
Haichar F, Marol C, Berge O, Rangel-Castro JI, Prosser JI, Balesdent J, Heulin T, Achouak W (2008) Plant host habitat and root exudates shape soil bacterial community structure. ISME J 2:12211230. https://doi.org/10.1038/ismej.2008.80

He YH, Cheng WX, Zhou LY, Shao JJ, Liu HY, Zhou HM, Zhu K, Zhou XH (2020) Soil DOC release and aggregate disruption mediate rhizosphere priming effect on soil $\mathrm{C}$ decomposition. Soil Biol Biochem 144:107787. https://doi.org/10.1016/j.soilbio.2020.107787

Holtkamp R, van der Wal A, Kardol P, van der Putten WH, de Ruiter PC, Dekker SC (2011) Modelling $\mathrm{C}$ and $\mathrm{N}$ mineralisation in soil food webs during secondary succession on ex-arable land. Soil Biol Biochem 43:251-260. https://doi.org/10.1016/j.soilbio.2010.10.004

Huo CF, Luo YQ, Cheng WX (2017) Rhizosphere priming effect: A meta-analysis. Soil Biol Biochem 111:78-84. https://doi.org/10.1016/j.soilbio.2017.04.003

Jones DL, Kemmitt SJ, Wright D, Cuttle SP, Bol R, Edwards AC (2005) Rapid intrinsic rates of amino acid biodegradation in soils are unaffected by agricultural management strategy. Soil Biol Biochem 37:1267-1275. https://doi.org/10.1016/j.soilbio.2004.11.023

Jones DL, Nguyen C, Finlay RD (2009) Carbon flow in the rhizosphere: carbon trading at the soilroot interface. Plant Soil 321:5-33. https://doi.org/10.1007/s11104-009-9925-0

Komarov A, Chertov O, Bykhovets S, Shaw C, Nadporozhskaya M, Frolov P, Shashkov M, Shanin V, Grabarnik P, Priputina I, Zubkova E (2017) Romul_Hum model of soil organic matter formation coupled with soil biota activity. I. Problem formulation, model description, and testing. Ecol Model 345:113-124. https://doi.org/10.1016/j.ecolmodel.2016.08.007

Kuzyakov Y (2002) Factors affecting rhizosphere priming effects. J Plant Nutr Soil Sci 165:382-396. https://doi.org/10.1002/1522-2624(200208)165:4\%3C382::AIDJPLN382\%3E3.0.CO;2-\%23

Kuzyakov Y, Hill PW, Jones DL (2007) Root exudate components change litter decomposition in a simulated rhizosphere depending on temperature. Plant Soil 290(1-2):293-305. https://doi.org/10.1007/s11104-006-9162-8

Liu Y, Ge T, Ye J, Liu S, Shibistova O, Wang P, Wang J, Li Y, Guggenberger G, Kuzyakov Y, Wu J (2019) Initial utilization of rhizodeposits with rice growth in paddy soils: Rhizosphere and $\mathrm{N}$ fertilization effects. Geoderma 338:30-39. https://doi.org/10.1016/j.geoderma.2018.11.040

Lynch JM, Whipps JM (1990) Substrate flow in the rhizosphere. Plant Soil 129:1-10. https://doi.org/10.1007/BF00011685

Mason-Jones K, Kuzyakov Y (2017) "Non-metabolizable” glucose analogue shines new light on Priming mechanisms: Triggering of microbial metabolism. Soil Biol Biochem 107:68-76. https://doi.org/10.1016/j.soilbio.2016.12.015 
Murphy CJ, Baggs EM, Morley N, Wall DP, Paterson E (2015) Rhizosphere priming can promote mobilisation of N-rich compounds from soil organic matter. Soil Biol Biochem 81:236-243. https://doi.org/10.1016/j.soilbio.2014.11.027

Parnas HA (1976) A theoretical explanation of the priming effect based on microbial growth with two limiting substrates. Soil Biol Biochem 8:139-144. https://doi.org/10.1016/00380717(76)90079-1

Pausch J, Tian J, Riederer M, Kuzyakov Y (2013) Estimation of rhizodeposition at field scale: upscaling of a ${ }^{14} \mathrm{C}$ labeling study. Plant Soil 364:273-285. https://doi.org/10.1007/s11104012-1363-8

Pei JM, Dijkstra FA, Li JQ, Fang CM, Su JH, Zhao JY, Nie M, Wu JH (2020) Biochar-induced reductions in the rhizosphere priming effect are weaker under elevated $\mathrm{CO}_{2}$. Soil Biol Biochem 142:107700. https://doi.org/10.1016/j.soilbio.2019.107700

Perveen N, Barot S, Alvarez G, Klumpp K, Martin R, Rapaport A, Herfurth D, Louault F, Fontaine S (2014) Priming effect and microbial diversity in ecosystem functioning and response to global change: a modeling approach using the SYMPHONY model. Glob Change Biol 20(4):1174-1190. https://doi.org/10.1111/gcb.12493

Phillips RP, Erlitz Y, Bier R, Bernhardt ES (2008) New approach for capturing soluble root exudates in forest soils. Funct Ecol 22:990-999. https://doi.org/10.1111/j.1365-2435.2008.01495.x

Qiao N, Schaefer D, Blagodatskaya E, Zou X, Xu X, Kuzyakov Y (2014) Labile carbon retention compensates for $\mathrm{CO}_{2}$ released by priming in forest soils. Glob Change Biol 20:1943-1954. https://doi.org/10.1111/gcb.12458

Qiao N, Xu X, Hu Y, Blagodatskaya E, Liu Y, Schaefer D, Kuzyakov Y (2016) Carbon and nitrogen additions induce distinct priming effects along an organic-matter decay continuum. Sci Rep 6:19865. https://doi.org/10.1038/srep19865

Sándor R, Ehrhardt F, Grace P, Recous S, Smith P, Snow V, Soussana J-F, Basso B, Bhatia A, Brilli L, Doltra J, Dorich C, Doro L, Fitton N, Grant B, Harrison M, Skiba U, Kirschbaum M, Klumpp K, Bellocchi G (2020) Ensemble modelling of carbon fluxes in grasslands and croplands. Field Crop Res 252:107791. https://doi.org/10.1016/j.fcr.2020.107791

Schimel JP, Weintraub MN (2003) The implications of exoenzyme activity on microbial carbon and nitrogen limitation in soil: a theoretical model. Soil Biol Biochem 35(4):549-563. https://doi.org/10.1016/S0038-0717(03)00015-4

Sommer J, Dippold MA, Flessa H, Kuzyakov Y (2016) Allocation and dynamics of C and N within plant-soil system of ash and beech. J Plant Nutr Soil Sci 179:376-387. https://doi.org/10.1002/jpln.201500384 
558 Sterner RW, Elser JJ (2002) Ecological stoichiometry: the biology of elements from molecules to the biosphere. Princeton University Press, Princeton, New Jersey, USA.

560 Wichern F, Mayer J, Joergensen RG, Muler T (2007) Rhizodeposition of C and N in peas and oats after ${ }^{13} \mathrm{C}-{ }^{15} \mathrm{~N}$ double labelling under field conditions. Soil Biol Biochem 39:2527-2537. https://doi.org/10.1016/j.soilbio.2007.04.022

Wild B, Lid J, Pihlblad J, Bengtsond P, Rütting T (2019) Decoupling of priming and microbial N mining during a short-term soil incubation. Soil Biol Biochem 129:71-79. https://doi.org/10.1016/j.soilbio.2018.11.014

Wu L, Xu H, Xiao Q, Huang Y, Suleman MM, Zhu P, Kuzyakov Y, Xu X, Xu M, Zhang W (2020) Soil carbon balance by priming differs with single versus repeated addition of glucose and soil fertility level. Soil Biol Biochem 148:107913. https://doi.org/10.1016/j.soilbio.2020.107913

Wutzler T, Reichstein M (2013) Priming and substrate quality interactions in soil organic matter models. Biogeosciences 10:2089-2103. https://doi.org/10.5194/bg-10-2089-2013

Zhou J, Zang H, Loeppmann S, Gube M, Kuzyakov Y, Pausch J (2020) Arbuscular mycorrhiza enhances rhizodeposition and reduces the rhizosphere priming effect on the decomposition of soil organic matter. Soil Biol Biochem 140:107641. https://doi.org/10.1016/j.soilbio.2019.107641

Zhu B, Gutknecht JLM, Herman DJ, Keck DC, Firestone MK, Cheng WX (2014) Rhizosphere priming effects on soil carbon and nitrogen mineralization. Soil Biol Biochem 76:183-192. https://doi.org/10.1016/j.soilbio.2014.04.033

Zhuravleva AI, Alifanov VM, Blagodatskaya EV (2018) Effect of contrasting trophic conditions on the priming effect in gray forest soils. Eurasian Soil Sci 51:204-210. https://doi.org/10.1007/s00374-019-01426-y 
582 Table 1 Parameters of the model and initial data for simulation at the ecosystem level Model parameters Parameters of modelling site at the ecosystem level

\begin{tabular}{|c|c|c|c|}
\hline Name & Value & Name & alue \\
\hline Bacteria $\mathrm{C}: \mathrm{N}$ ratio* & 5.0 & Soil horizon Ah C pool, $\mathrm{kg} \mathrm{m}^{-2}$ & 6.91 \\
\hline Fungi C:N ratio* & 11.0 & Soil horizon $\mathrm{Ah} \mathrm{N}$ pool, $\mathrm{kg} \mathrm{m}^{-2}$ & 0.49 \\
\hline Protozoa $\mathrm{C}: \mathrm{N}$ ratio & 7.0 & Fine root specific length, $\mathrm{m} \mathrm{m}^{-2}$ & 42.5 \\
\hline Nematoda $\mathrm{C}: \mathrm{N}$ ratio & 10.0 & Fine root diameter, $\mathrm{mm}$ & 1.5 \\
\hline $\begin{array}{l}\text { Microarthropoda } \mathrm{C}: \mathrm{N} \\
\text { ratio }\end{array}$ & 8.0 & Fine root dry weight, $\mathrm{kg} \mathrm{m}^{-2}$ & 0.068 \\
\hline Bacteria and Fungi: & & $\begin{array}{l}\text { Diameter of rhizosphere soil tube } \\
\text { (including root diameter), } \mathrm{mm}\end{array}$ & 7.5 \\
\hline $\begin{array}{l}\text { production } \\
\text { efficiency }\end{array}$ & 0.3 & Rhizosphere soil C pool, $\mathrm{kg} \mathrm{m}^{-2}$ & 0.0901 \\
\hline $\begin{array}{l}\text { respiration } \\
\text { efficiency }\end{array}$ & 0.7 & Rhizosphere soil $\mathrm{N}$ pool, $\mathrm{kg} \mathrm{m}^{-2}$ & 0.0064 \\
\hline $\mathrm{N}$ mining efficiency, $\mathrm{k}$ & $0 \ldots 1$ & $\begin{array}{l}\text { Root exudate } \\
\mathrm{kg}[\mathrm{C}] \mathrm{m}^{-2} \text { day }^{-1}\end{array}$ & $0.0001 \ldots 0.0005$ \\
\hline
\end{tabular}

Root exudate input, $0.5 \ldots 2.0$

$\mathrm{g}[\mathrm{C}] \mathrm{m}^{-2}$ day $^{-1}$

583 Note: The data of Bengtson et al. (2012), Chertov et al. (2011, 2017), Holtkamp et al. (2011), 584 Kuzyakov (2002), and Phillips et al. (2008) were used. Production efficiency (food web terminology) 585 corresponds to Carbon Use Efficiency (CUE, microbiological terminology).

$586 *$ For verification only. 
588 Fig. 1 Conceptual structure of the priming model to be linked to the SOM model Romul_Hum 589 (Komarov et al. 2017). State variables are represented by boxes; flows are represented by rounded 590 boxes. The plant-related components are represented with solid line, the microbial ones with dotted 591 line, the food web ones with dashed line, the SOM with dash-single dotted line, and the nitrogen (N) 592 mining processes with dash-triple dotted line. All is in carbon mass units. Root exudates are input 593 from plant to soil. $\mathrm{CO}_{2}$ emission at mineralisation of exudates and $\mathrm{SOM}$ (due to $\mathrm{N}$ mining and from 594 rhizosphere soil) represents priming. Available $\mathrm{N}$ and faunal by-products are a feedback from priming 595 to plant and soil

Fig. 2 Measured and modelled results of priming effects observed in two sets of experiments. Left columns are experimental data for agricultural soil (Blagodatsky et al. 2010), and for subtropical forest soil (Qiao et al. 2016). B - microbial community represented by bacteria only with biomass

$600 \mathrm{C}: \mathrm{N}$ ratio $5, \mathrm{~F}-$ microbial community represented by fungi only with biomass $\mathrm{C}: \mathrm{N}$ ratio 11 . In the 601 Cropland data, number of observations is 1 , in the forest, it is 16 . The bars are standard deviation 602

603 Fig. 3 Simulated effect of extra $\mathrm{C}$ mineralisation at priming effect ( $R_{n m}$ in eq. 9$)$ from rhizosphere SOM depending on the amount of exudate input and their $\mathrm{C}: \mathrm{N}$ ratio

Fig. 4 Simulated C-CO $\mathrm{CO}_{2}$ efflux at priming depending on the exudates input and their $\mathrm{C}: \mathrm{N}$ ratio as related to the bulk pool of mineralized $\mathrm{C}$ in a whole Ah horizon (input $1.20 \mathrm{~g}[\mathrm{C}] \mathrm{m}^{-2} \mathrm{day}^{-1}$; $\mathrm{SOM}$ pool $7.00 \mathrm{~kg}[\mathrm{C}] \mathrm{m}^{-2}$ ) over 20 days

Fig. 5 Simulated impact of microorganisms' biomass C:N ratio on nitrogen mining $\left(R_{n m}\right.$ in eq. 9$)$ at 611 priming effect

613 Fig. 6 Simulated dynamics of microbial growth at exudate input on ecosystem level testing. MB_RE 614 - microbial biomass growth using $\mathrm{C}$ and $\mathrm{N}$ of exudates; $\mathrm{MB}$-mng - the same due to $\mathrm{N}$ mining for the 615 microbial growth using the rest of exudates $\mathrm{C}$

617 Fig. 7 Cumulative $\mathrm{N}$ mineralization available for root uptake in the rhizosphere. $\mathrm{N}$ is mineralized 618 from two sources: priming N (solid line) and mineralized N in rhizosphere soil (SON) without exudate 619 input (dotted line). The lag phase in the figure is the effect of the daily time step of model and because microbial biomass need to growth first before PE can be produced 
622 Fig. 8 Simulated cumulative carbon and nitrogen fluxes in the tested forest soil (Ah horizon, pools of 623 soil $\mathrm{C}$ and $\mathrm{N}$ are 7.00 and $0.49 \mathrm{~kg} \mathrm{~m}^{-2}$, respectively) with a regular root exudates input ( $\mathrm{C}$ and $\mathrm{N}$ are 6240.5 and $0.0125 \mathrm{~g} \mathrm{~m}^{-2}$ day $^{-1}$ ) during 30 days. $P E_{t o t}$ and $R_{n m}$ are total priming and SOM respiration for $625 \mathrm{~N}$ mining, respectively; $N M$ is the $\mathrm{N}$ mining. The sum of $\mathrm{C}$ and $\mathrm{N}$ fluxes is 53 and $2.6 \mathrm{~g} \mathrm{~m}^{-2} \mathrm{month}^{-1}$, 626 respectively 


\section{Figures}

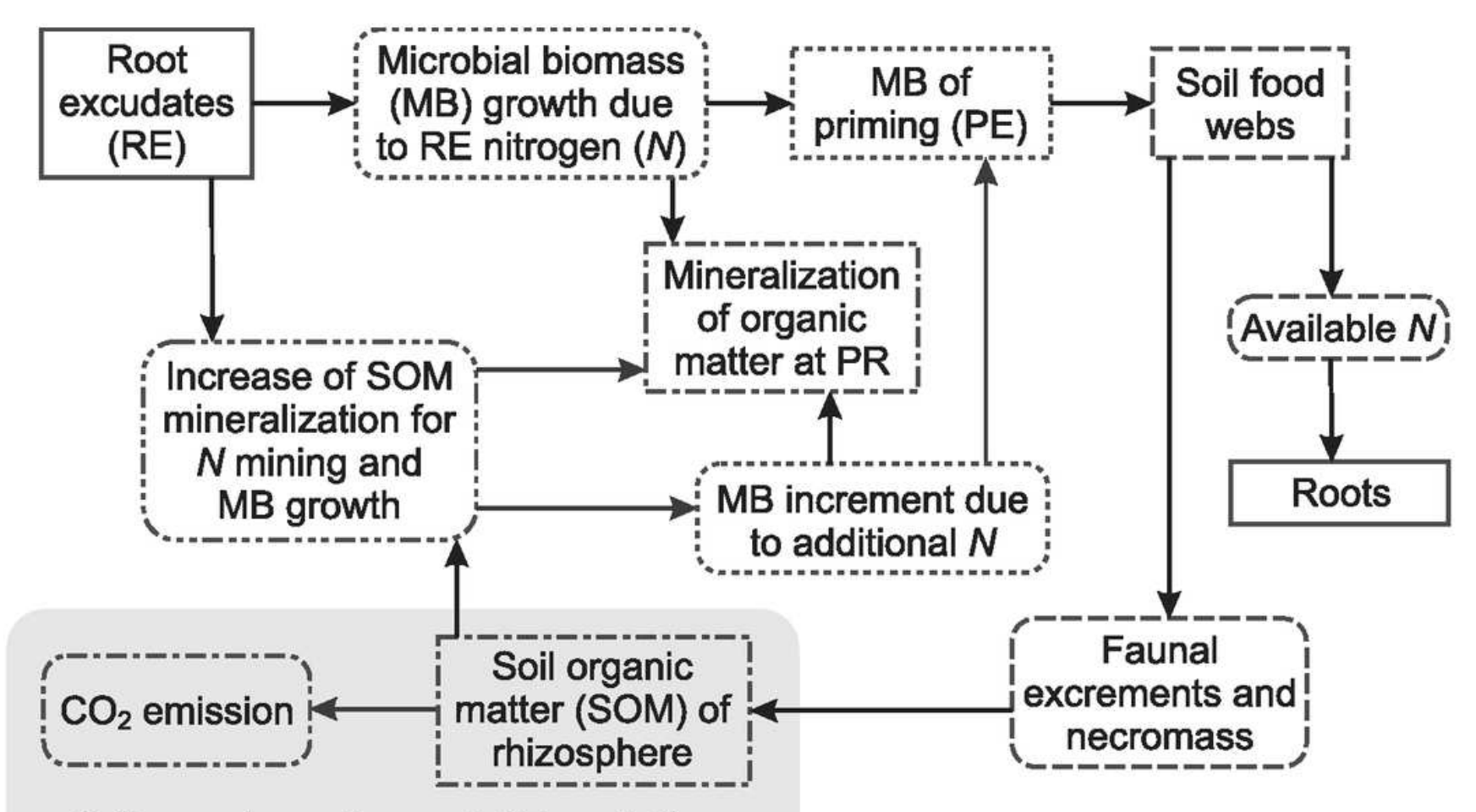

Soil organic matter model Romul_Hum

Figure 1

Conceptual structure of the priming model to be linked to the SOM model Romul_Hum (Komarov et al. 2017). State variables are represented by boxes; flows are represented by rounded boxes. The plantrelated components are represented with solid line, the microbial ones with dotted line, the food web ones with dashed line, the SOM with dash-single dotted line, and the nitrogen $(\mathrm{N})$ mining processes with dashtriple dotted line. All is in carbon mass units. Root exudates are input from plant to soil. $\mathrm{CO} 2$ emission at mineralisation of exudates and SOM (due to $\mathrm{N}$ mining and from rhizosphere soil) represents priming. Available $\mathrm{N}$ and faunal by-products are a feedback from priming to plant and soil 


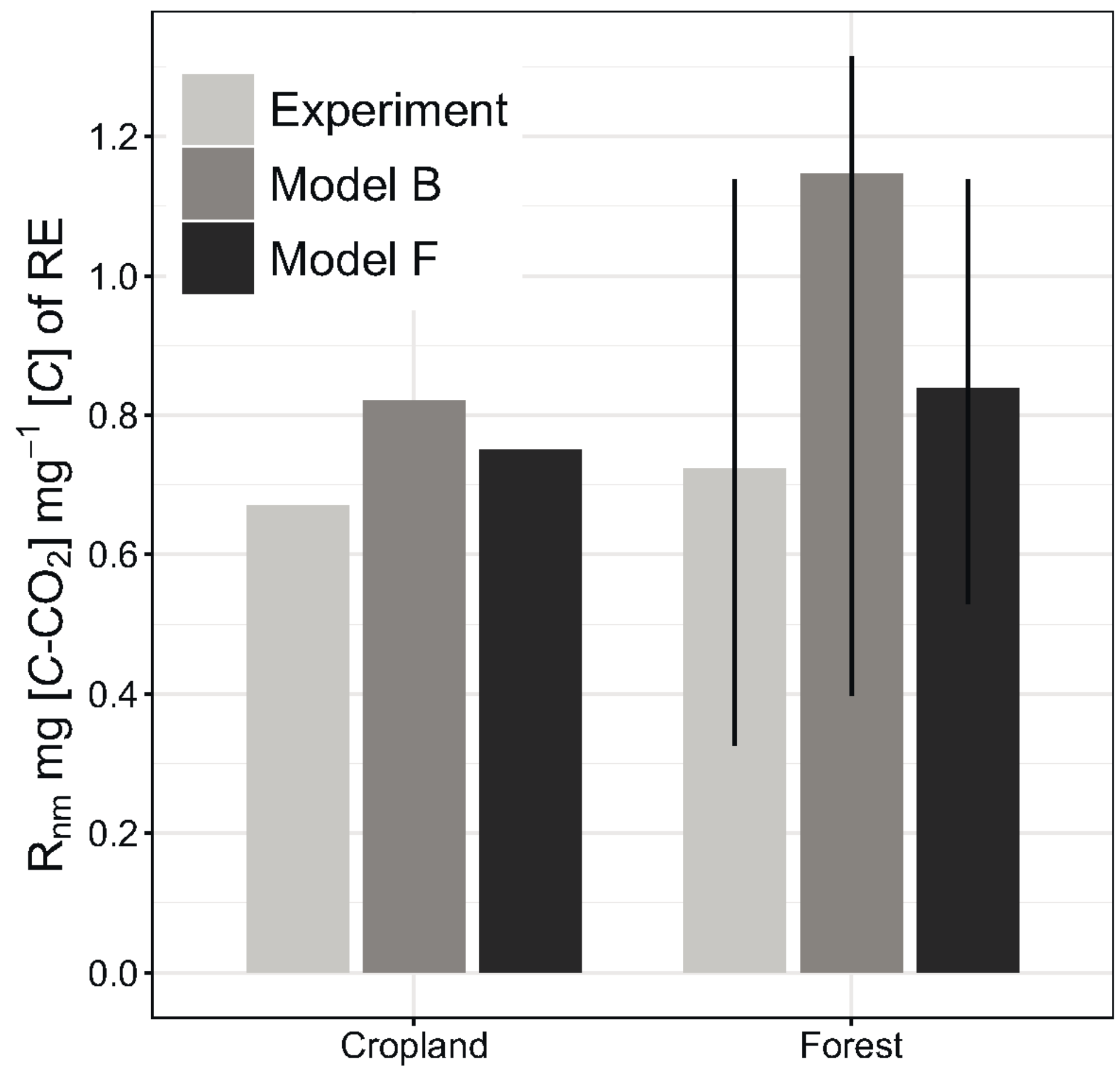

Figure 2

Measured and modelled results of priming effects observed in two sets of experiments. Left columns are experimental data for agricultural soil (Blagodatsky et al. 2010), and for subtropical forest soil (Qiao et al. 2016). B - microbial community represented by bacteria only with biomass C:N ratio 5, F - microbial community represented by fungi only with biomass $\mathrm{C}: \mathrm{N}$ ratio 11 . In the Cropland data, number of observations is 1 , in the forest, it is 16 . The bars are standard deviation 


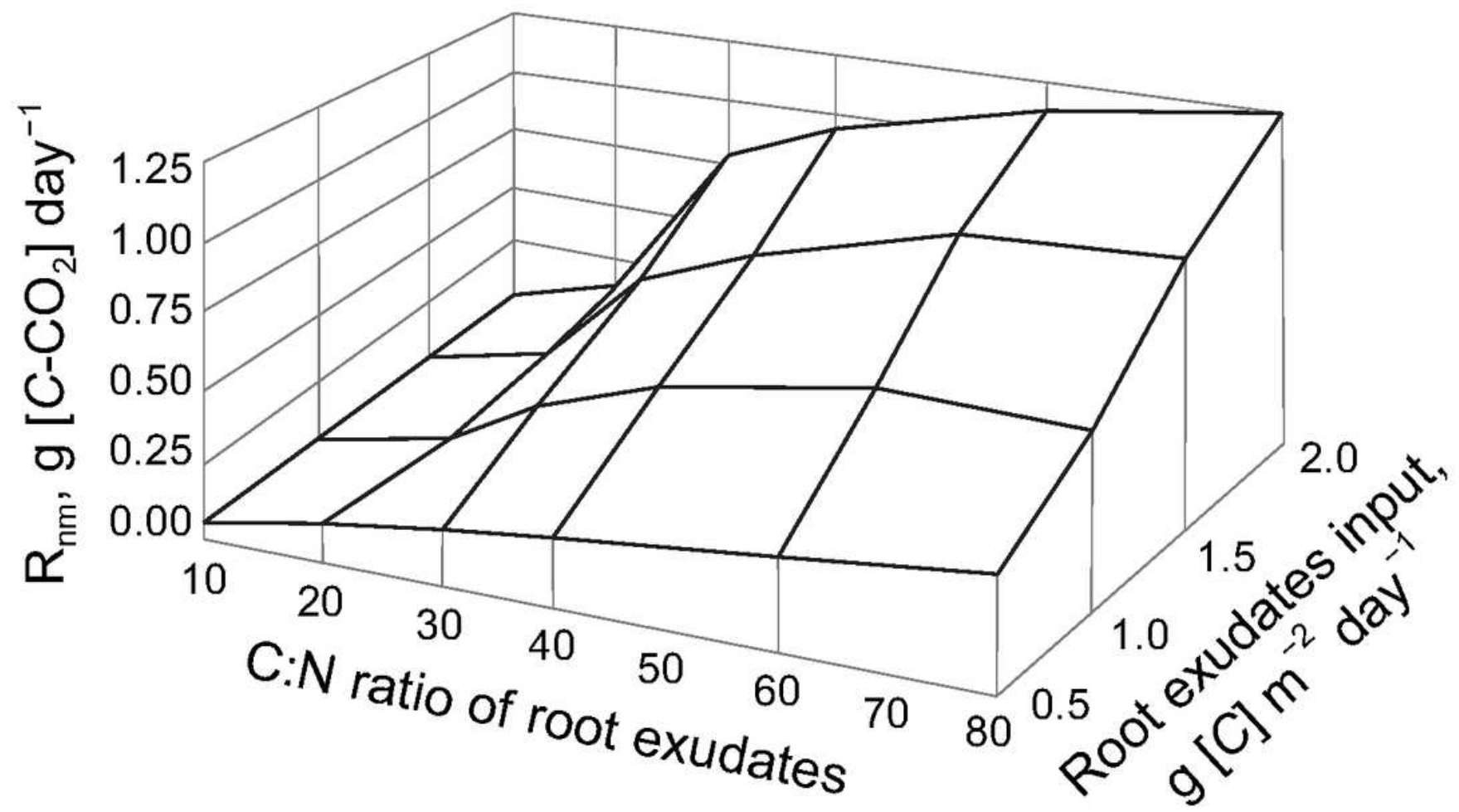

Figure 3

Simulated effect of extra $\mathrm{C}$ mineralisation at priming effect (Rnm in eq. 9) from rhizosphere SOM depending on the amount of exudate input and their $\mathrm{C}: \mathrm{N}$ ratio 


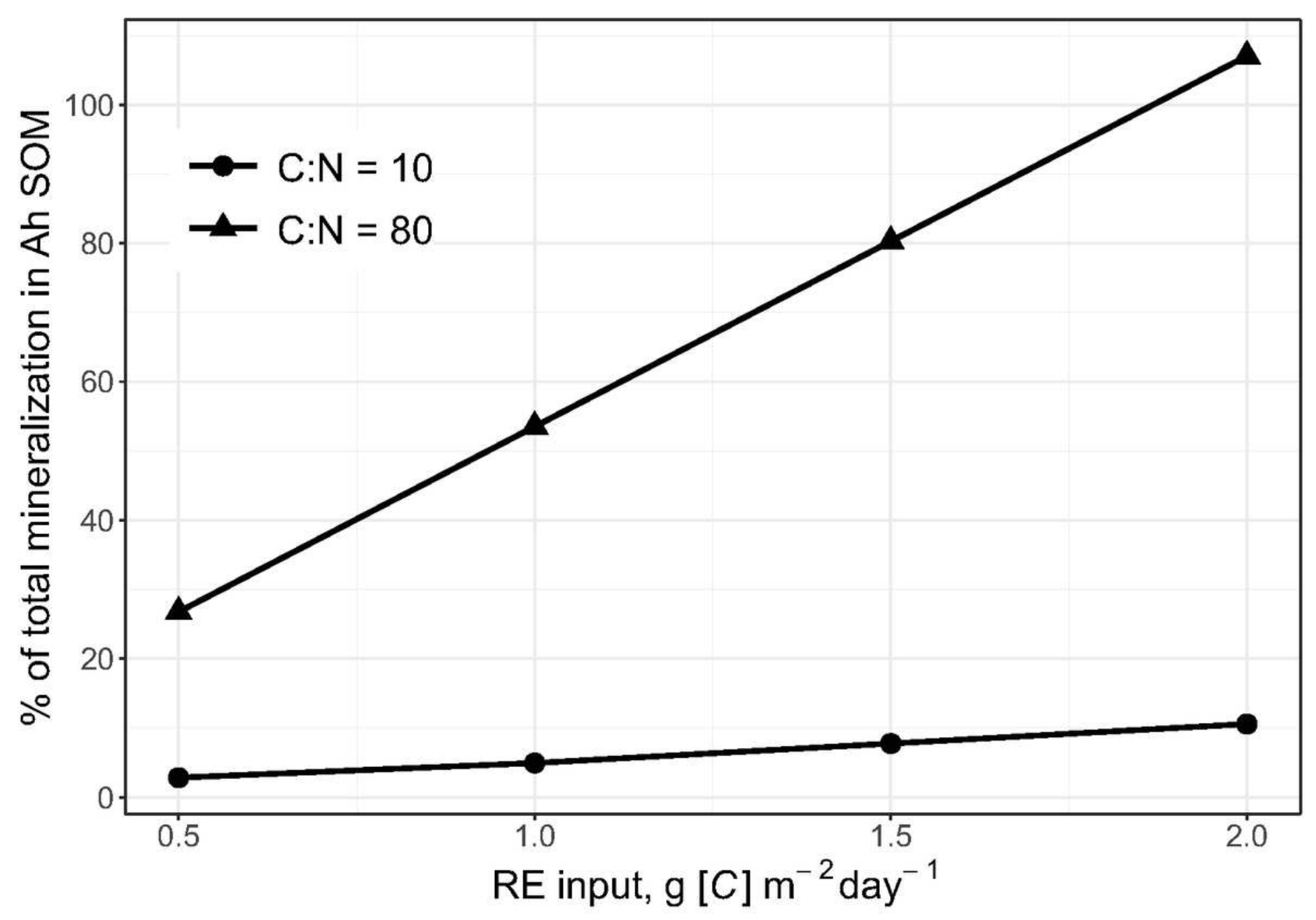

Figure 4

Simulated C-CO2 efflux at priming depending on the exudates input and their $\mathrm{C}: \mathrm{N}$ ratio as related to the bulk pool of mineralized $\mathrm{C}$ in a whole Ah horizon (input $1.20 \mathrm{~g}$ [C] m-2 day-1; SOM pool $7.00 \mathrm{~kg}$ [C] m-2) over 20 days 


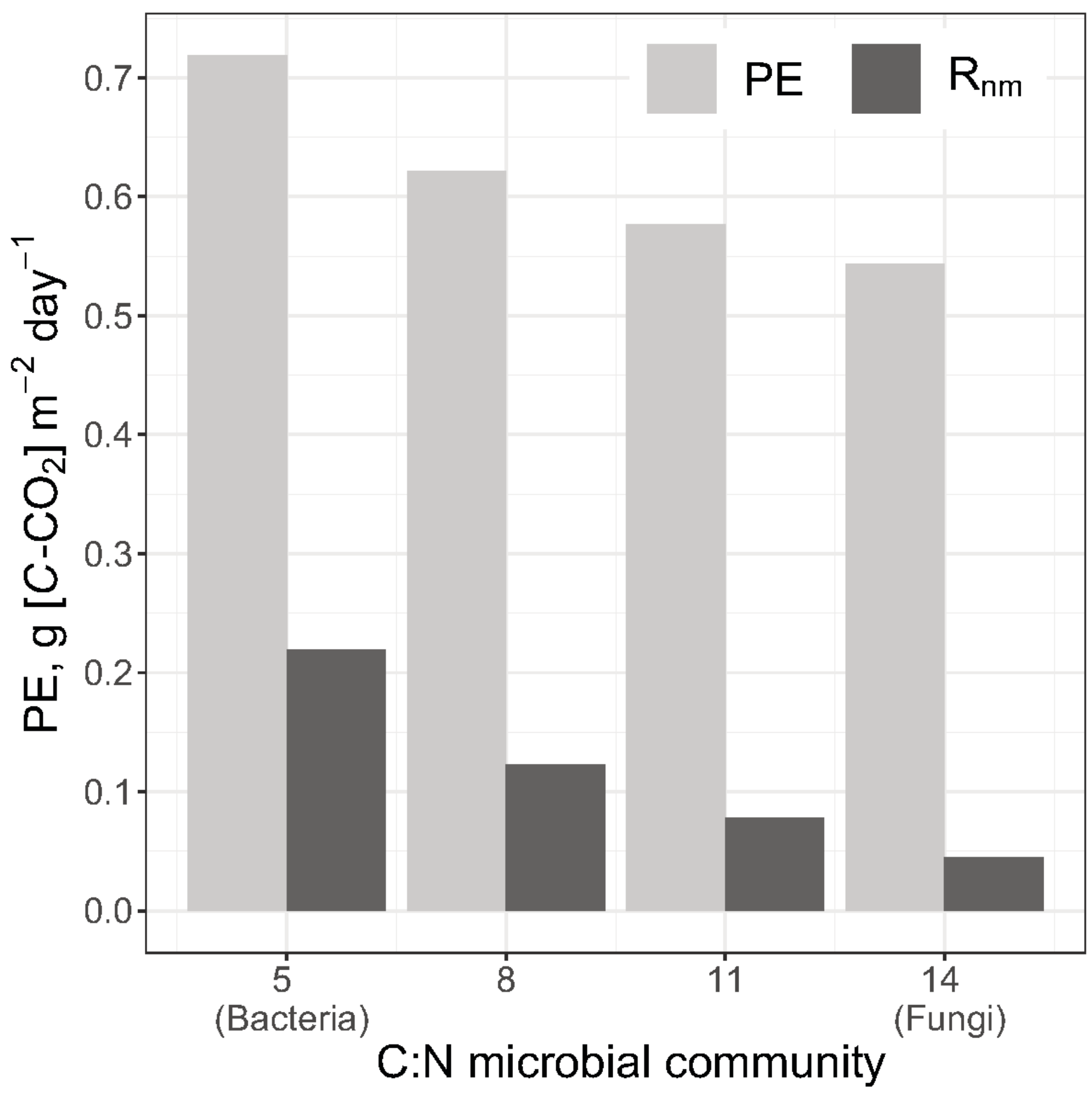

Figure 5

Simulated impact of microorganisms' biomass $\mathrm{C}: \mathrm{N}$ ratio on nitrogen mining (Rnm in eq. 9) at priming effect 


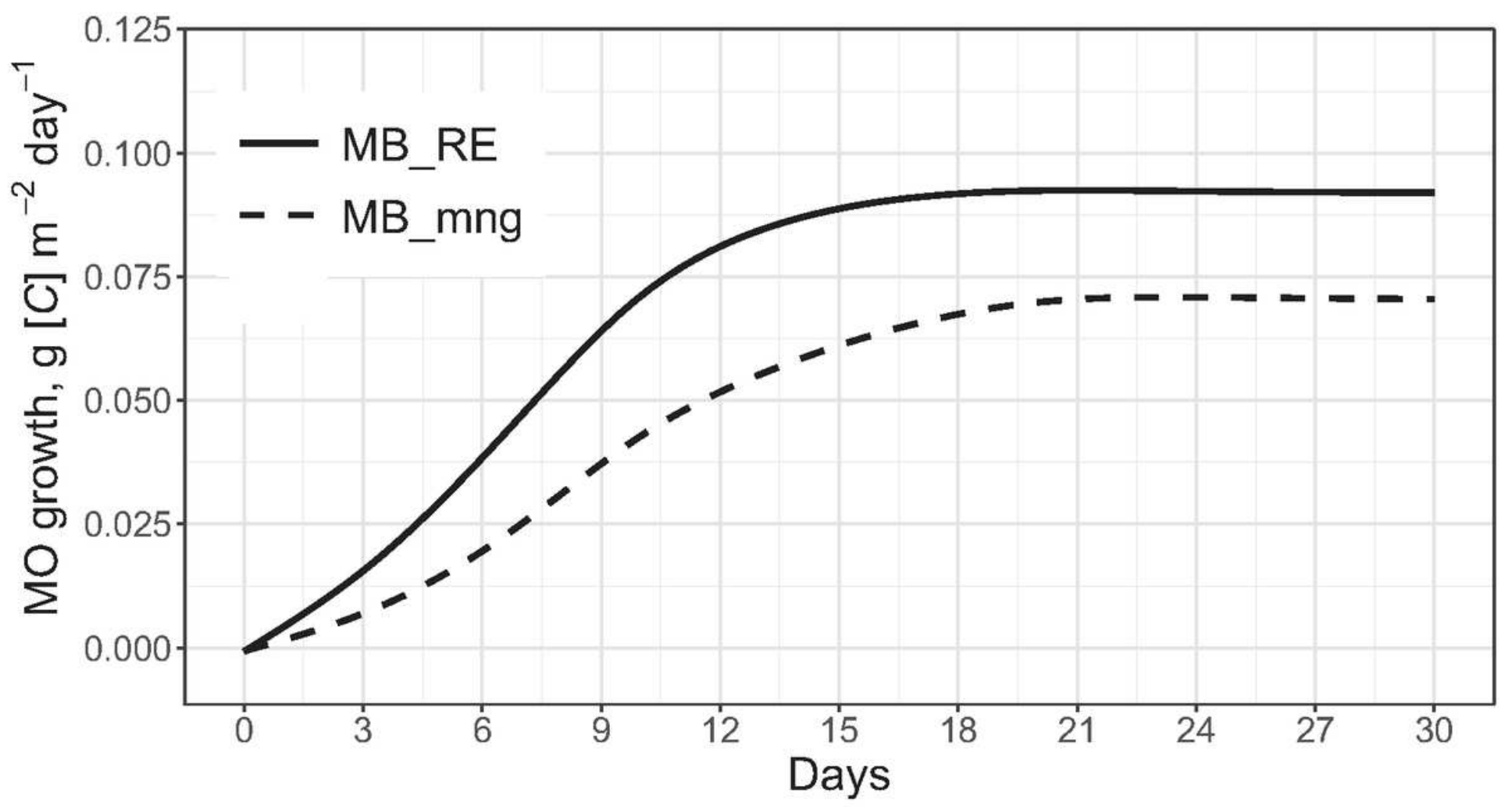

Figure 6

Simulated dynamics of microbial growth at exudate input on ecosystem level testing. MB_RE - microbial biomass growth using $\mathrm{C}$ and $\mathrm{N}$ of exudates; $\mathrm{MB} \_\mathrm{mng}$ - the same due to $\mathrm{N}$ mining for the microbial growth using the rest of exudates $\mathrm{C}$ 


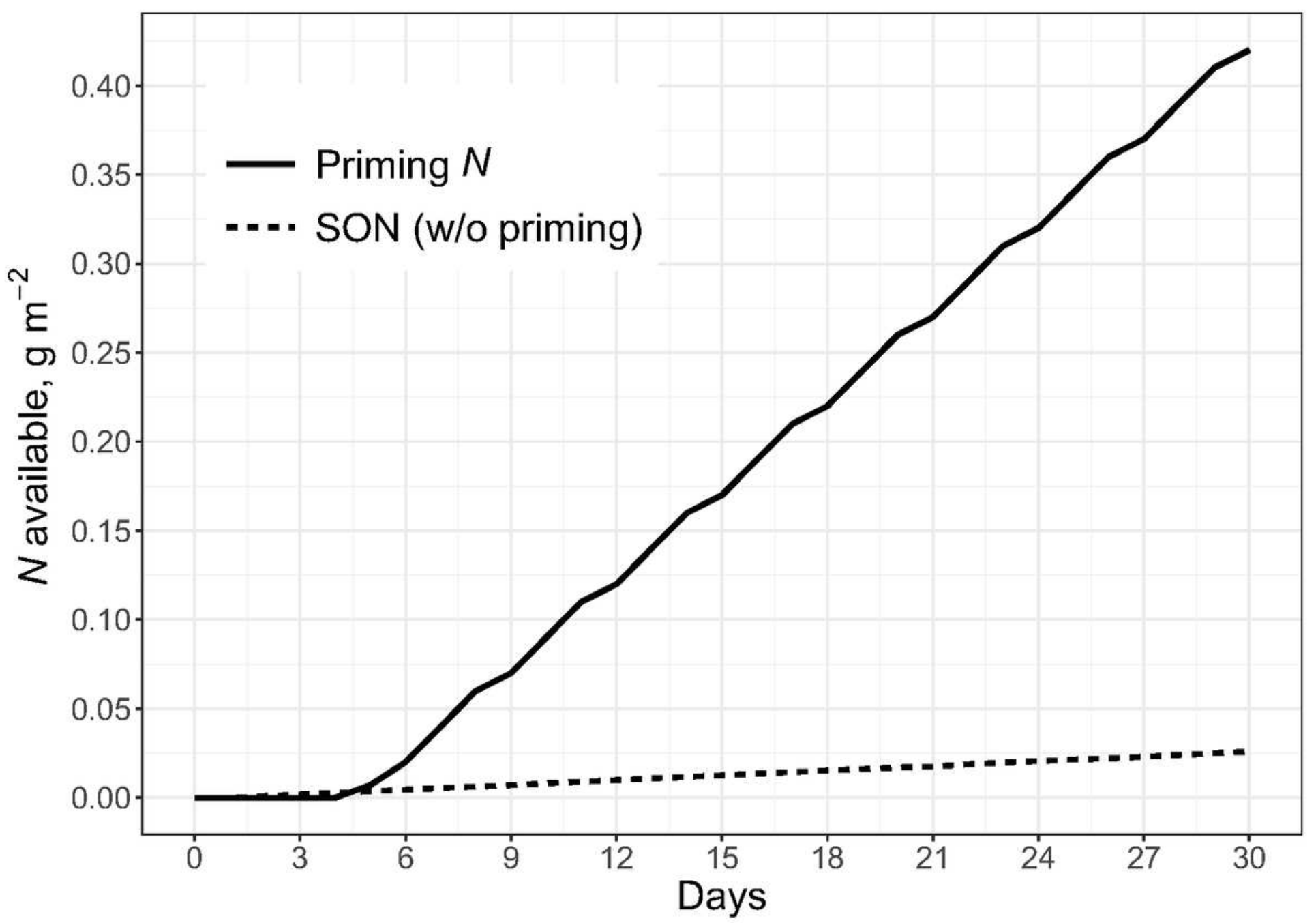

Figure 7

Cumulative $\mathrm{N}$ mineralization available for root uptake in the rhizosphere. $\mathrm{N}$ is mineralized from two sources: priming $\mathrm{N}$ (solid line) and mineralized $\mathrm{N}$ in rhizosphere soil (SON) without exudate input (dotted line). The lag phase in the figure is the effect of the daily time step of model and because microbial biomass need to growth first before PE can be produced 


\section{Carbon}

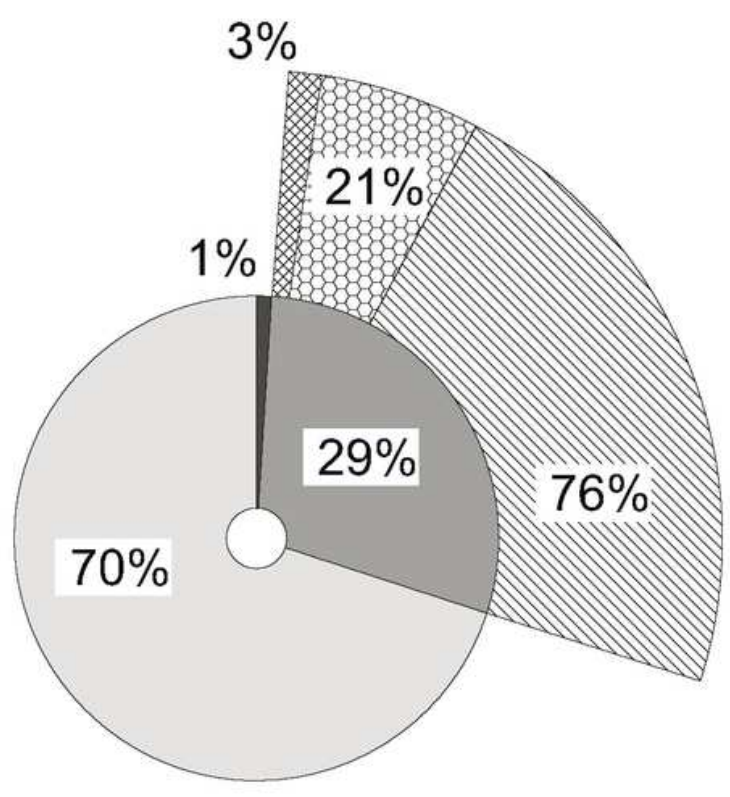

Nitrogen

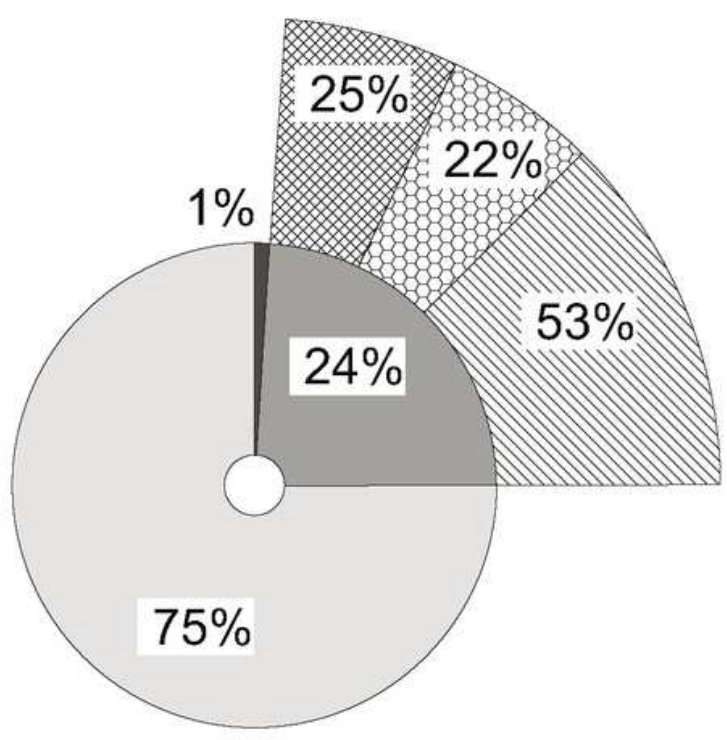

$P E_{\text {tot }}$

Food webs

\section{Figure 8}

Simulated cumulative carbon and nitrogen fluxes in the tested forest soil (Ah horizon, pools of soil $\mathrm{C}$ and $\mathrm{N}$ are 7.00 and $0.49 \mathrm{~kg} \mathrm{~m}-2$, respectively) with a regular root exudates input ( $\mathrm{C}$ and $\mathrm{N}$ are 0.5 and 0.0125 $\mathrm{g} \mathrm{m}-2$ day-1) during 30 days. PEtot and Rnm are total priming and SOM respiration for $\mathrm{N}$ mining, respectively; NM is the $\mathrm{N}$ mining. The sum of $\mathrm{C}$ and $\mathrm{N}$ fluxes is 53 and $2.6 \mathrm{~g} \mathrm{~m}-2$ month-1, respectively 